\title{
Muhasabah Diri Sebagai Media Penanggulangan Perilaku Juvenile Delinquency
}

\author{
Iqbal Syafri', Hudzaifah Achmad Qotadah'2, Adang Darmawan Achmad ${ }^{3}$ \\ 1Sunan Kalijaga State Islamic University Yogyakarta, Yogyakarta, Indonesia \\ ${ }^{2}$ Department of Fiqh and Usul, Acedemy of Islamic Studies, University of Malaya, \\ Malaysia \\ ${ }^{3}$ Muhammadiyah University of Cirebon, Indonesia \\ e-mail: Workoutfaculty@gmail.com
}

\begin{abstract}
Adolescence is a stage of transition from childhood to adulthood which might flood each adolescent with curiosity regarding new stuff. It is indeed time for an adolescent to either be assessed whether he's motivated to do something positive rather than just taking some action that would harm himself, his family, as well as others. Educational institutions therefore have a huge responsibility to address juvenile delinquency. Therefore, this is a must for any school to provide a good approach, for instance by using selfmuhasabah (intropectsion). The research employed a full qualitative method and data documentation through the interview method where Madrasah Muallimin Muhammadiyah Yogyakarta as the research location, which was then analyzed descriptively. In the meantime, the results of the study revealed that the practices of self-muhasabah (intropection) in the form of client-centered therapy such as muraqabah, muhasabah, mujahadah and mu'atabah have already shown impressive outcomes in eliminating juvenile delinquency in class X.
\end{abstract}

Keywords: Behaviour, Juvenile Delinquency, Introspection, Islamic Education

\begin{abstract}
ABSTRAK
Masa remaja adalah masa perubahan seseorang dari kanak-kanak menuju dewasa, dalam tahap ini seorang remaja akan diliputi rasa ingin tahu terhadap hal-hal yang baru. Ketika menghadapi hal tersebut, saat itulah seorang remaja diuji a pakah dia akan melakukan hal yang baik atau malah akan terjerumus ke perbuatan-perbuatan yang akan merugikan dirinya, keluarganya bahkan merugikan orang lain. Karenanya, tanggung jawab terhadap kenakalan remaja itu salah satunya terletak dari sekolah sehingga sudah seyogyanya setiap sekolah memiliki langkah penyelesaian yang konkret salah satunya dengan menggunakan media muhasabah diri. Metode penelitian ini bersifat kualitatif dengan mengambil latar Madrasah Muallimin Muhammadiyah Yogyakarta sebagai lokasi penelitian. Adapun, hasil penelitian menunjukkan bahwa kegiatan muhasabah diri yang berupa client centered theraphy seperti muraqabah, muhasabah, mujahadah, dan mu'atabah telah menunjukkan hasil yang positif dalam menanggulangi kenakalan remaja (Juvenile Delinquency) di kelas X secara efektif.
\end{abstract}

kata kunci: Perilaku, Juvenile Delinquency, Muhasabah Diri, Pendidikan Agama Islam

\section{PENDAHULUAN}

Pendidikan memiliki peranan yang amat signifikan dalam mentranformasikan suatu keadaan masyarakat untuk menjadi lebih baik dimana pendidikan berfungsi untuk memperkenalkan generasi muda pada pengenalan terhadap kewajiban dan tanggung jawabnya di tengah masyarakat. Selain itu menurut Mahmud bahawa pendidikan juga bermakna sebagai proses sosial ketika seseorang dihadapkan pada pengaruhlingkunganyang terpilih dan terkontrol (khususnyalingkungan sosial), sehingga mereka dapat memperoleh kemampuan sosial dan perkembangan individual secara optimal [Mahmud,2011].

* Copyright (c) 2020 Iqbal Syafri et.all

This work is licensed under a Creative Commons Attribution-ShareAlike 4.0 International License. 
Khazanah Pendidikan Islam, Vol. 2 No. 3: 126-138

Muhasabah Diri Sebagai Media Penanggulangan Perilaku Juvenile Delinquency

Iqbal Syafri et.all

Sejatinya, Madrasah Muallilim Muhammadiyah Yogyakarta merupakan sebuah sekolah yang berkonsepkan boarding school (asrama), bertujuan untuk menciptakan generasi peserta didik agar senantiasa memiliki budi pekerti yang luhur serta akhlakyang karimah dalam bersosial dengan individu lainnya. Karenanya, sudah menjadi sebuah kewajiban bagi peserta didik untuk dapat mewujudkan proses belajar mengajar yang kondisif dan sejalan dengan visi serta misi madrasah. Akan tetapi, tidak ada siapapun yang dapat memberikan jamninan bahwa peserta didik madrasah (siswa) akan dapat mewujudkan apa yang menjadi visi maupun misi madrasah. Hal demikian ini dapat kita lihat bahwa meskipun adanya tata tertib atau aturan yang berlaku di sekolah ataupun madrasah tetap saja masih didapati beberpa pelanggaran yang berkaitan dengan perbuatan juvenile delinquency seperti misalnya merokok, ber-khalwat dan lain-lain.

Maka, sudah semestinya setiap institusi pendidikan mempunyai langkah penyelesaian yang konkret dalam rangka menanggulangi perbuatan-perbuatan juvenile delinquency di kalangan para peserta didik. Salah satu langkah yang mungkin dapat dijalankan oleh institusi pendidikan ialah dengan mengadakan kegiatan muhasabah diri bagi setiap peserta didik sehingga mereka dapat tersadar terhadap setiap perbuatan yang dapatmerugikan dirinya sendiri maupun pihaklain dan Umar bin Khattab pernah berkata:

"Perhitungkanlah diri kalian sebelum kalian diperhitungkan, timbanglah diri kalian sebelum kalian ditimbang, karenaitu lebih memudahkan penghisaban bagi kalian kelak, Berhiaslah untuk menghadapi hari perhitungan [Al-'Ulyawi,2007].

Adapun kajian terdahulu mengenai boarding school pernah di telitioleh Asyhari (2013) mengenai Program Musyrif Untuk Meningkatkan Motivasi Belajar Siswa Kelas XII Madrasah Muallimin Muhammadiyah Yogyakarta dan menghasilkan bahwa program musyrif dalam menguatkan motivasi belajar siswa melalui berbagai macam program di antaranya program ibadah,kedisiplinan dan pendidikan secara umum dan musyrif jugam enjadi central motivator dalam membina dan memberikan arahan untuk mensukseskan program pembelajaran diasrama sekaliguspersiapan Ujian Nasional. Penelitian yang dilkukan oleh Noor (2014) mengenai judul Strategi Musyrif(Pendamping Asrama) dalam Meningkatkan Perilaku Ibadah Siswa di Asrama Umar Bin Khattab Madrasah Muallimin Muhammadiyah Yogyakarta dan menghasilkan bahwa Musyrif dalam meningkatkan perilaku ibadah siswa di asrama yaitu dengan memberikan reward bagi santri yang berprestasi di asrama dan pemberian punishment bagi siswa yang melanggar peraturan madrasah.

Penelitianyang dikaji oleh Rifa'i (2009) mengenai Kenakalan Remaja di Kalangan SantriPuteradi Asrama Diponegoro PondokPesantren Yayasan Ali Maksum Krapyak Yogyakarta dimana penelitian hanya membahas seputar sebab maupun bentuk kenakalan remaja di pondok pesantren dan upaya yang dilakukan pembimbingasrama dalam menanggulanginya.

Alhasil, penelitian yang dilakukan oleh Asyhari (2013) hanya menjelaskan tentang motivasi belajar yang dikaitkan dengan upaya Musyrif sedangkan penelitian yang dijalankan oleh Noor (2014) hanya membicarakan seputar strategi musyrif dalam meningkatkan kulaitas dan kuantitas ibadah para siswa. Adapun penelitian yang dilakukan oleh Rifa'i (2009) secara umum tidakmembahas sedikitpun mengenai kegiatan muhasabah diri dalam menanggulangi juvenile delinquency

Dengan demikian, berdasarkan pemaparan diatas, penulisakan mengkaji mengenai "Muhasabah Diri Sebagai Media Penanggulangan Perilaku Juvenile Delinquency

(studi kasus Kelas X di Madrasah Mu'allimin Muhammadiyah Yogyakarta)." Adapun objektif daripada penelitian ini ialah untuk mengetahui bentuk dan sebab terjadinya perbuatan juvenile delinquency dikalangan santri kelas X Madrasah Mu'allimin Muhammadiyah Yogyakarta serta hasil 
pencapaian kegiatan muhasabah diri yang telah dijalankan madrasah dalam menanggulangi perbuatan juvenile delinquency.

\section{METODE PENELITIAN}

Metode yang digunakan penulis dalam penelitianini ialah dengan menggunakan metode kualitatif penuh serta data dokumentasi yang terkait dengan topik kajian penelitian ini, kemudian dianalisis secara deskriptif. Penulis menggunakan dua instrumen kajian iaitu kajian perpustaka an dan wawancara (interview) dengan berbagai responden dari Madrasah Muallimin Muhammadiyah Yogyakarta. Penulis menggunakan metode penelitian criterion based selection dalam memilih subjek penelitian berdasarkan asumsi bahwa subjek tersebut sebagai aktor dalam sebuah penelitian. Adapun, responden dalam menjalankan wawancara (interview) adalah sebagaimanaberikut:

1. Kepala/Direktur Madrasah Muallimin Muhammadiyah Yogyakarta

Kepala/Direktur Madrasah merupakan pemimpin yang memiliki kewajiban dalam menjamin manajemen organisasi dan sumber daya madrasah. Serta bertanggung jawab terhadap pelaksanaan pembelajaran disekolah (formal) maupun diasrama (informal).

2. Guru Bimbingan dan Konseling (BK)

Guru Bimbingan dan Konseling berwenang untuk melakukan tindak bimbingan dan konseling terhadap siswa-siswayang melakukan perilaku kenakalan remaja beserta solusinya.Guru Bimbingan dan Konseling memiliki catatan-catatan perilaku kenakalan remaja yang sering dilakukan oleh para siswa yang akan dijadikan dokumentasi penulis terkait bentuk-bentuk kenakalan remaja yang dilakuakn oleh para siswa.

3. Musyrif(pendamping/wali di asrama)

Musyrifialah wali santri yang berwenang untuk membimbing, mengarahkan dan mengayomi para santri di asrama sekaligus bertanggung jawab dalam mendampingi santri di asrama. Sehingga penulis dapat mengamati, mewawancarai dan mendokumentasikan secara langs ung peran musyrif dalam menerapkan konsep muhasabah diri bagi parasantri.

4. Siswa kelas X

Siswa merupakan sumber data penelitian, karena siswa merupakan unsur penting dalam pelaksanaan pembelajaran. Data yang diperoleh adalah hasil pengamatan langsung yang akan dilaksanakan di asrama, wawancara dan hasil dokumentasi yang berhubungan dengan kecenderungan perilaku kenakalan remaja.

\section{HASIL DAN PEMBAHASAN}

\section{Kenakalan Remaja (Juvenile Delinquency)}

MenurutKamus Besar Bahasa Indonesia (KBBI) kata "remaja” secara etimologi bermakna mulai dewasa, sudah sampai umur untuk menikah. Adapun dalam istilah asing dikenal dengan puberteit, adolescentia, dan youth yang seringdigunakan untuk menujukkan masaremaja [Depdiknas, 2008].

Adapun definisi daripada kenakalan remaja (Uuvenile delinquency) ialah perbuatan anti sosial yang dilakukan oleh anak remajayang bilamana dilakukan orang dewasadi kualifikasikan sebagai tindak kejahatan [Sudarsono, 2004]. Adapun, Anglo Saxon mendefinisikan juvenile delinquency sebagai perbuatan dan tingkah laku yang merupakan perbuatan perkosaan terhadap norma hukum pidana dan pelanggaran-pelanggaran terhadap kesusilaan yang dilakukan oleh anak-anak remaja, juvenile 
delinquency itu adalah offenders (pelaku pelanggaran) yang terdiri dari "anak" (berumur di bawah 21 tahun/pubertas), yang termasuk yurisdiksi pengadilan anak (juvenile court) [Sudarsono, 2004].

Secara terminologi, para ahli memiliki pandangan yang berbeda dalam merumuskan masa remaja, di antaranya menurut Zakia Daradjat bahwa masa remaja ialah masa dimana anak-anak mengalami pertumbuhan cepat di segala bidang, mereka bukan lagi anak-anak baik secara bentuk jasmani, cara berfikir, sikap maupun tindakan tetapi bukan pula orang dewasa yang telah matang dan ini kira-kira bermula pada umur 13 tahun dan berakhir sekitar umur 21 tahun [Zakiah, 2007].

MenurutArifin (2006) bahwa sebaiknya batasusia bawah ialah13 tahun dan batasusia atas ialah 17 tahun baik laki-laki maupun perempuan danyang belum menikah. Dengan demikian, maka kenakalan yang dilakukan oleh anak di bawah umur 13 tahun dikategorikan dalam kenakalan "biasa" dan sebaliknya kenakalan yang dilakukan oleh anak usia 18 tahun ke atas dikategorikan dalam tindak pelanggaran atau kejahatan. Penentuan batas usia tersebut berdasarkan beberapa alasan antaranya, menurut data yang diperoleh selama ini bahwa kenalakan remaja banyak terjadi dalam bentuk dan sifatyang dilakukan oleh anakusia 13 tahun sampai dengan anak usia 17 tahun dimana bentuk kenakalanyang dilakukan oleh anak usia di bawah 13 tahun pada umumnya belum begitu serius dan membahayakan dibandingkan dengan anak usia 13 tahun ke atas. Adapun, kenakalan yang dilakukan anak usia di atas 18 tahun adalah dipandang sudah menjelang dewasa yang telah terkena sanksi hukum.

\section{Muhasabah Diri}

Pengertian menurut bahasa, kata muhasabah berasal dari Bahasa Arab yaitu الْمَحَاسَّang yang bermakna hitungan [Munawwir, 1997]. Muhasabah (introspeksi diri) adalah memperhatikan dan merenungkan hal-hal baik dan buruk yang telah dilakukan. Termasuk memperhatikan niat dan tujuan suatu perbuatan yang telah dilakukan, serta menghitung untung dan rugi suatu perbuatan. Ini sekaligus pula sebagai persiapan untuk hari-hari mendatang, dengan tekad baru yang lebih lurus dan teguh [Karzon, 2012].

Muhasabah juga dapat diartikan sebagai perenungan diri untuk menghitung apa yang telah kita lakukan sebelum Allah SWT menghisab amal kita pada Hari Pembalasan. Merenung, melakukan introspeksi, mawas diri kemudian melakukan perbaikan dan peningkatan prestasi semaksimal mungkin [Bachrun, 2011].Jadi, Muhasabah ialah segala kegiatan yang mencakup perhitungan yang dilakukan oleh seseorang terhadap dirinya sendiri tentang perbuatan yang sudah dilalui, yang sedang dijalani, dan perbuatan yangakan datang.

Adapun dalil-dalil mengenai pentingnya Muhasabah bagi setiap insan khususnya muslim ialah sepertimana berikut:

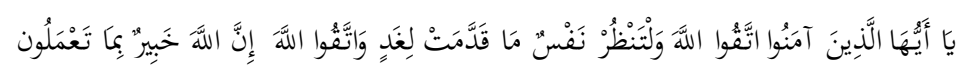

Artinya: "Hai orang-orang yang beriman, bertaqwalah kepada Allah dan hendaklah setiap diri memperhatikan apa yang telah diperbuatnya untuk hari esok (akhirat), dan bertaqwalah kepada Allah.Sungguh, Allah Maha Mengetahuiapayangkamu kerjakan." (QS. Al-Hasyr:18)

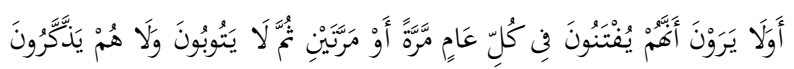

Artinya:" Dan tidakkah mereka (orang-orang munafik) memperhatikan bahwa mereka diujisekali atau dua kali setiap tahun, kemudian mereka tidak (juga) bertaubat dan tidak (pula) mengambil pelajaran?" (QS At-Taubah:126) 
Begitujuga dalam hadits Rasulullah bersabda:

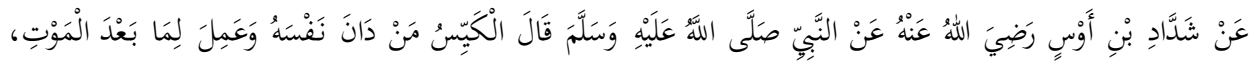

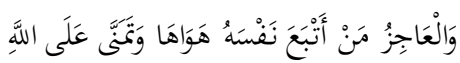

Artinya: "Dari Syadad bin Aus ra, dari Nabi Muhammad SAW bahwa beliau bersabda, 'Orangyang cerdas (sukses) adalah orangyang menghisab (mengevaluasi) dirinya sendiri, serta beramal untuk kehidupan sesudah kematiannya. Sedangkan orangyang lemah adalah orang yang mengikuti hawa nafsunyaserta berangan-angan terhadap Allah SWT [Mubārakfürī, 1963]."

\section{Bentuk-bentuk Muhasabah}

Setidaknya setiap manusia yang beriman kepada Allah dan Hari Kiamat akan melakukan enam (6) hal yang dipandang perlu dalam memperkokoh niat introspeksi diri sebagaimana berikut [Azhar, 2014]:

\section{Musyarathah}

Musyarathah bermakna memberikan motivasi pada diri sendiri untuk melakukan amalan yang terbaik pada hari ini.

\section{Muraqabah}

Muraqabah ialah suatu keadaan merasa diawasi oleh Allah dimana seorang hamba apabila menjalankan sebuah ketaatan, ia melakukannya dengan ikhlas, dan muraqabah-nya ketika melakukan kemaksiatan dengan bertaubat, istighfar, menyesal dan meninggalkannya.

\section{Muhasabah}

Muhasabahialah bilamana seoranghamba mempunyai waktu pagi untuk mengajukan syaratsyarat kepada dirinya, seyogianyaia juga mempunyai waktu untuk mengevaluasi, dan menginvestigasi dirinya atas semua yangtelah dilakukannya.

\section{Mu'aqabah}

Mu'aqabah bermaksud menghukum diri sendiri karena melakukan kesalahan atau berbuat kebaikan kurang maksimal dan seyogianya ia menghukum diri dengan hukuman yang diperbolehkan.

\section{Mujahadah} kebaikan.

Mujahadah merupakan perbuatan dalam mengoptimalisasikan atau memaksimalkan amalan

\section{Mu'atabah}

Yaitu perbuatan yang dimaksudkan untuk mengkritikjiwa (memberi kritik terhadap dirisendiri).

Dengan demikian, enam (6) tingkatan muhasabah itu, berlaku dalam enam aspek. Akidah spiritual, materi finansial, moral sosial, pengetahuan intelektual, nafsu emosional, dan dakwah.

\section{Bentuk-bentuk Juvenile Delinquency Siswa Kelas X di Madrasah Mu'allimin Muhammadiyah Yogyakarta}

Dalam hasil penelitian yang telah dilakukan, penulis menemukan berbagai macam pola atau bentuk kenakalan remaja siswa X yang biasa terjadi di Madrasah Muallimin Muhammadiyah Yogyakarta yang dapat diklasifikasikan diantaranya sebagai berikut: 
Khazanah Pendidikan Islam, Vol. 2 No. 3: 126-138

Muhasabah Diri Sebagai Media Penanggulangan Perilaku Juvenile Delinquency

Iqbal Syafri et.all

\section{Kenakalan yang Menimbulkan Korban Fisik}

Perilaku delinquen yang menyebabkan korban fisik pada orang lain juga pernah dan sering terjadi di kelas X ini dimana senioritas merupakan salah satu sebab terjadinya perilaku delinquen ini. Hal tersebut pernah dilakukan oleh salah seorang siswayang bernama Zulfan Mumtaz, siswa kelas X IPS2.

"Paling mukuladik kelas, itu waktu nyidang. Saya dorong juga sape terjatuh. Berkelahi saya pernah juga. Bully juga sering.Sampe nangistemen saya pernah [Zulfan,2017]."

Ustadz Anies Fahmi Basewed, sebagai BK kelas X juga menambahkan terkait dengan adanya kenakalan atau kekerasan yang menimbulkan korban fisik sebagai berikut:

"Ya ada beberapa kekerasan fisik karena senioritas. Tapi itu tidakdilakukan secara masif. Biasanya senioritasitu diwadahi dalam sebuah organisasi siswa. Ya senioritas tentu ada, dengan satu syarat ketika adik kelas ini bertindak tidak sopan dengan kaka kelas. Biasanya senoiritas itu terjadi di acara malam latih mental, itukan terjadi karena adek kelas dianggap tidak sopan dengan kakak kelas, nah ketika itulah sebagian oknum kakak kelas gak kontrol juga dan beberapa ada yang melakukan kekerasan, seperti pemukulan, perploncoan, dan sebagainya. Biasanya juga kalau ada kehilangan antar asrama, mereka melakukan investigasi tanpa sepengetahuan ustadz. Mereka menindak dengan cara kekerasan terhadap pelaku yag diduga mencuri barang di salah satu asarama [Zulfan, 2017]."

Karenanya, tindak kenakalan ini termasuk tindak kenakalan yang dapat membawa dan menjerumuskan seorang pelaku kekerasan fisik pada sebuah tindak pidana, dengan syarat jika korban melaporkan kepada orang tua, lalu orang tua melakukan fisum dan mendatangkan pihak yang berwajib untuk menangkap pelaku. Lebih fatal lagijika kekerasan fisikini dapat menciderai korban hingga korban kehilangan salah satu fungsi organ tubuhnya atau bahkan kematian. Hal ini dapat merugikan pihak sekolah dan mencemarkan nama baik sekolah. Sehingga, dalam kaitan kasus ini, pihak sekolah mengedepankan tindakan preventif maupun represif untuk menanggulangi kekerasan fisikyang terjadi di sekolah.

\section{Kenakalan Sosial yang Tidak Menimbulkan Korban di Pihak Lain}

Macam-macam kenakalan ini terjadi dan sering dilakukan oleh siswa Madrasah Muallimin Muhammadiyah, seperti; sering bermain playstation dan game online,lompat pagar asrama, mencuri soal ujian, memakai jeans, keluar tanpa izin musyrif, menonton video porno dan sebagainya. Hal demikian ini sepertimana yang dikatakan oleh Ustadz Dedik Fatkul Anwar sebagai Wakil Direktur Madrasah Muallimin Muhammadiyah Yogyakarta sebagai berikut:

"Kalo kasusterbaru, yang sedang kitaproses itu ada anakyang mencurisoal ujian. Itu juga termasuk dalam pelanggaran berat. Konsekuensinya bukan hanya dikelaurkan saja, tapi juga kita diskualifikasi dari ujian. Adajuga yang sering pakai celana jeans, main game online juga ada. Seperti merokok, point-nya tigapuluhan, lompat pagar dan sebagainya [Anwar, 2017].

Dan diperkuat juga oleh pernyataan salah seorang siswa yang bernama Zulfan Mumtaz.

"Pulang malem sering, jam 2 jam 3 pagi. Lompat pager masuk asramanya. Ngerokok sama bawa hape pernah. Kalo ngerokok di angkringan, saya kalo ngerokok di luar. Biasanya sehari ya habis sebatang dua batang lah. Saya belum bisa berhenti kalo kebiasaan yang sa tu ini mas. Nonton video porno juga pernah.Itu waktu di warnet [Zulfan, 2017]."

Ada pula pelanggaran yang dapat dikategorikan pelanggaran sosial, yaitu pelanggaran berkhalwat. Sebagaimana yang dikatakan oleh musyrif X IPS 2, Ustadz Sidiq Oktavianto memaparkan sebagai berikut: 
"Ada yang gak sholat, itu termasuk pelanggaran religius. Ada juga yang gak Sholat Jum'at, dan alesannya emang ketiduran gitu. Tapi secara disengaja. Tapi saya selalu menanamkan dari awal, supaya gimana caranya kalian itu harus sholat. Biasanya yang menjadi rawan itu waktu Ashar, karena anakitu tidur siangbiasanya bablassampai Maghrib.Subuh juga.Sebab kalogak adayang bangunin mereka gak pada bisa bangun sendiri. Kalo yang pelanggaran berat ya, pacaran ada, khalwat itu ada, berdua-duaan sama lawan jenis, bisa langsung dikeluarkan. tapi kadang sampai batas mananya saya juga kurang tahu. Tapi itu ada [Oktavianto, 2017]."

Dan juga pernyataan seorang siswa bernama Ardiyantara,ia mengatakan:

"Saya pacaran itu ya karena suka sama cewek. Masih labil juga. Temen juga ada yang kayak gitu. Jadi ikut ikutan juga. Biasanya kalo pacaran itu ya nonton, jalan-jalan, nongkrong di cafe. Kadang juga di warnet berduaan. Saya juga pernah minum minuman keras, dulu. Motif saya mabuk itu ya ikut-ikut temen. Coba-coba. Rasanya gimana ya, pusing pusing gitu. Sebab setelah mabuk, Cuma bisanya diem ditempatitu (teler) gak bisa ngapa-ngapain [Ardiyantara,2017].

Sayangnya, beberapa kenakalan sosialyang biasa terjadi di Madrasah Muallimin Muhammadiyah Yogyakarta kebanyakan tidak tercatat dan tidak diketahui oleh bimbingan konseling, musyrif, maupun kedisiplinan siswa. Karena mudahnya siswa dalam mencuri waktu dan situasi secara diam-diam serta perilaku tersebut sudah menjadi sebuah kebiasaan yang dapat diprediksi untuk mendapatkan celah kesempatan oleh sipelaku.

3. Kenakalan yang melawan status

Adapun kenakalan tersebut meliputi; jarang masuk sekolah, konvoi suporter bola, nakal, urakan, dan lain-lain. Hal tersebut sepertimana pengakuan salah seorang siswa kelasX aliyah.

“Konvoi suporteran. Itu habis nonton pertandingan bola. Sama temen keluar bareng-bareng. Mau nggak mau ya khirnya juga ikut konvoijuga [Ardiyantara, 2017].

Hal ini dibenarkan oleh Guru BK KelasX Aliyah, Ustadz AnisFami Basewed mengatakan:

“Di kelas 1 Aliyah ini, kebanyakan saya tangani adalah merokok. Lalu awalnya futsalan, mereka jadi supportergitu, mereka naik motor, konvoi, sambil merokok di jalan raya, divideo, lalu diupload di internet. Nah itukan jadi pelanggaran yang banyak sekali d an bisa akumulatif dalam sekali waktu. Pelanggaran itu adalah salah satu pelanggaran yang bersifat masif Bahkan klub futsalnya itu juga sempat kami bekukan. Kemudian kami skros. Lalu darisana anak mulai frustasi, anak-anak mulai melakukan penentangan [Basewed, 2017].

Itulah bentuk pelanggaran atau kenakalan moralitas yang penulis temukan di dalam kehidupan siswa kelas X aliyah Madrasah Muallimin Muhammadiyah Yogyakrta. Meskipun hanya beberapa orang yang melakukan pelanggaran tersebut, tetapi dampak, pengar uh, dan kesan yang ditimbulkan dari sebuah pelanggaran tersebut sangat bersifat serius dan dapat mencoreng nama baik Madrasah Muallimin Muhammadiyah sebagai sekolah kader berbasis Agama Islam dalam kehidupan bermasyarakat.

4. Kenakalan yang Menimbulkan Korban Materi

Kenakalan jenis ini sangat sering terjadi di berbagai lembaga pendidikan, khususnya di Madrasah Muallimin Muhammadiyah Yogyakarta seperti misalnya perbuatan vandalism dimana siswa melakukan pengerusakan terhadap sarana dan prasarana penunjang kegiatan belajar mengajar di sekolah. Hal demikian ini diperkuat oleh pernyatan siswa kelas X IPS2 bernama Ardiyantara danZulfan Mumtas.

"Waktu di sekolah itu biasanya ya di meja kadang lagi suntuk di kelas, nggambarin meja, kursi. Termasuk ngerusak. Biasanya juga sering saya buat mainan sama temen temen. Terus ada kursi yang patah [Ardiyantara, 2017]." 
"Waktu itu saya sama temen-tem en gak masuk kelas, nykip pelajaran. Saya pernah dipanggil sama BK gara-gara narik kursi kantin kelantai dua pakai tali. Terus saya jatuhkan sampe rusak. Itu bareng bareng sama temen. Yaitu saya pengen aja. Bikin seru-seruan sama temen-temen (sambil tertawa) [Zulfan, 2017]."

Seharusnya fasilitas maupun sarana prasarana yang disediakan sekolah untuk menunjang kegiatan belajar mengajar digunakan dan dimanfaatkan sebagaimana semestinya. Karenanya, perlu kesadaran seorang peserta didik untuk merasa memiliki fasilitas dan sarana prasarana di sekolah harus ditanamkan seintensif mungkin, guna mencegah kenakalan yang bersifat vandalisme, dalam kata lain kenakalanyang memunculkan korban materi.

Selain itu merujuk pada data yang didapatkan dari KS (Kedisiplinan Siswa) pelanggaran yang tercatat dapat diketahui bahwa kasusyang paling sering dilanggar oleh santri dapat dilihat pada tabel1:

Tabel I. Pelanggaran Santri

\begin{tabular}{lcc}
\hline No. & Jenis Pelanggaran & Jumlah Santri \\
\hline 1. & Supporteran & 35 \\
2. & Membawa Motor & 7 \\
3. & Konvoi & 15 \\
4. & Membawa dan menggunakan HP & 1 \\
5. & Merokok & 3 \\
6. & Pakaian Tidak Sopan & 3
\end{tabular}

Dari penjelasan diatas dapat diketahui bahwa terdapat banyakbentukatau pola pelanggaran yang dilakukan oleh parasantri kelas X aliyah Madrasah Muallimin Muhammadiyah Yogyakarta.

\section{Sebab-sebab perbuatan juvenile delinquency Siswa Kelas X di Madrasah Mu'allimin Muhammadiyah Yogyakarta}

Adapun latar belakang atau sebab terjadinya perbuatan juvenile delinquency ialah amat beragam di antaranya sebagaiberikut:

1. Peralihan masa jenjang pendidikan sepertimanayang dituturkan oleh siswa kelas X IPS 2 Lauzafia M. Naila Suye, dia mengatakan:

"Ya kan ini u dah kelas X. Udah bukan tsanawiyah lagi. Jadi peraturannya agak longgar. Sama ini juga, kata kakak kelas, masa kelas X iniadalah surganya di Muallimin. Jadi saya pengen ngerasain gimana sih seneng-seneng di sini sebelum nanti punya tanggung jawab di organisasi [Suye, 2017]."

2. Paksaan orang tua murid, ustadz Dedik Fatkul Anwar selaku wakil direktur bagian kesiswaan menuturkan bahwa:

"Ada juga sebenarnya dia itu tidak ingin melanjutkan di Muallimin, dianggak kerasan, dipaksa sama orang tuanya. Kemudian dia menunjukkan rasa ketidak rasanan itu, ya dia cari masalah [Anwar, 2017]." 
3. Munculnya rasa kebosanan, ustadz AniesFahmi Basewed mengatakan bahwa:

"Stress dan rasa bosan itu ada pastinya. Lalu larinyaya merokok, stress lalu nonton konser, nah itu ada yang ketahuan, lalu kita hukum. Kita beri sanksi [Basewed, 2017]."

Hal ini yang dirasakan oleh salah seorang siswa bernama Lauzafia M. Naila Suye bahwa:

"Kalo ngerokok saya di luar asrama. Ya itu mas, saya kalo ngerokok buat ngilangin bosen. Kan di asrama terus-terusan suntuk, jadi bawaannya pengen keluar asrama terus ngerokok di luar. Kadang sendiri, kadang ya sama temen. Bawa handphone juga. Tapi sekarang udah disita ustadz Nonton video porno jugapernah. Saya nontonnya di warnet [Suye, 2017]."

4. Kegagalan rumah tangga (broken home), ustadz Dedik Fatkul Anwar mengatakan bahwa:

"Ada beberapa siswa kita itu yang mengalami broken homeya, orang tuanya bermasalah. Adayang cerai, ada juga masalah yang kami sendiritidak dapat menjangkau informasinya. Kadang salah satu pelarian dia (siswa) itu juga disitu (melakukan kenakalan). Nah, kadang kami merasa kasihannya disitu [Anwar, 2017]."

5. Pengaruh teman sejawat sepertimana pengakuan salah seorangsiswa bernama Lauzafia M. Naila Suye mengatakan sebagai berikut:

"Dulu kalo nggembel (tidak tidur di asrama) di indomaret point. Terus paginya kita main. Ke goa cemara. Bawa motor juga. Saya nyewa motor. Sama yang anak jogja main bareng. Kalo nggembel biasanya empat sampe lima orang gitu. Kalo nggembel saya bia sanyajanjian, kesepakatan bersama sama temen. Ketemuan disuatu tempat [Suye,2017]."

Hal ini ikut dibenarkan oleh guru BK mereka, Ustadz Anies Fahmi Basewed mengatakan:

"Dan kalaupun dia butuh teman untuk melanggar, dia juga bisa mengajak-ajak yang lain. Dan akhirnya temannya itu juga goyah pendidiran. Tadinya sih yang diajak kadang gak mau, tapi ada tekanan dari temennya, atau iming-iming sesuatu. Nah jadinya si anak ini akhirnya ikut-ikutan [Basewed, 2017]."

Jenis dan Motif Kenakalan siswa dapatdilihat lebih rinci pada tabel 2.

Tabel 2. Jenis dan Motif Kenakalan Siswa Kelas X

\begin{tabular}{|c|c|c|}
\hline No. & Bentuk-bentuk Kenakalan Remaja & Sebab- sebab Kenakalan Remaja \\
\hline 1. & $\begin{array}{l}\text { Kenakalan yang menimbulkan korban } \\
\text { fisik bagi orang lain }\end{array}$ & $\begin{array}{l}\text { 1. Siswa Mulai Memasuki Tingkat } \\
\text { Senior (Aliyah) di Madrasah } \\
\text { (Senioritas) }\end{array}$ \\
\hline 2. & $\begin{array}{l}\text { Kenakalan yang menimbulkan korban } \\
\text { materi }\end{array}$ & 1. Rasa Bosan \\
\hline 3. & $\begin{array}{l}\text { Kenakalan sosial yang tidak } \\
\text { menimbulkan korban dipihak lain }\end{array}$ & $\begin{array}{l}\text { 1. Lokasi Asrama yang Memudahkan } \\
\text { Siswa untuk Melakukan } \\
\text { Pelanggaran } \\
\text { 2. Pengaruh Teman Sejawat } \\
\text { 3. Rasa Bosan }\end{array}$ \\
\hline 4. & Kenakalan yang melawan status & $\begin{array}{l}\text { 1. Paksaan Orang Tua } \\
\text { 2. Kegagalan Adaptasi } \\
\text { Lingkungan Madrasah } \\
\text { 3. Pengaruh Teman Sejawat }\end{array}$ \\
\hline
\end{tabular}


4. Kegagalan Rumah Tangga

\section{Hasil Pencapaian Kegiatan Muhasabah Diri terhadap penanggulangan Perilaku Juvenile Delinquency di Kelas X Madrasah Mu'allimin Muhammadiyah Yogyakarta}

Muhasabah adalah segala prosesyang berkaitan tentang pengenalan kepada dirisendiri dengan melakukan autokritik supaya seseorang dapat menga mbil segala pelajaran terhadap segala perbuatanperbuatan yang telah dilakukan. Kegiatan muhasabah pula merupakan suatu proses evaluasi dirisekaligus bentuk perbuatan seseorang dalam menunjukkan rasa syukur kepada Allah SWT.

Kegiatan muhasabah diri yang telah dilakukan oleh para siswa kelas X telah memberikan kesan positif terhadap perilaku, pemikiran, kondisi psikis, dan perencanaan, dimana para siswa berkomitmen untuk tidak mengulangi perbuatan-perbuatan juvenile delinquency di masa mendatang. Hal demikian ini sepertimana yang dikatakan Ustadz Dedik Fatkul Anwar selaku wakil direktur bagian kesiswaan bahwa:

"Sebetulnya dari pola pembinaan itu kan kita ingin memberikan penyadaran pada anak yang bermasalah. Dan pola pembinaan itu bersifatbertahap. Mulai dari musyrif, pamong asrama, BK, dan seterusnya. Pembinaan pertama dari musyrif, dia diajak untuk merenungi bahwa adik-adik ini dibina dan dididik supaya menjadi seorang kader. Maka konsekuensi logisnya, dia harus menampilkan diri selayaknya perilaku seorang kader itu. Sejauh ini program-program yang kami selenggarakan seperti kegiatan muhasabah terbukti telah memberikan hasil yang positif. Terjadi perubahanyangsignifikan terkait dengan perilaku-perilaku remaja yang menyimpang di kalangan anak-anak kelasX aliyah itu sendiri, begitu [Anwar, 2017]."

Dan ikut diperkuat oleh pernyataan Ardiyantara siswa kelasX IPS 2, dia mengatakan:

"Saya punya komitmen, dari semuanya itu ya saya ingin berubah lah. Kan yang namanya jadi manusiaya ada salahnya. Hari besok dan seterusnya harus lebih baik. Kalo gak darisekarangkan kita bisa merugi. Semakin kesini ya semakin memperbaiki diri. Semakin berintrospeksi diri, semakin bertambah usia juga harussemakin baik mas. Kan gak mungkinjadi kayagitu terus. Kalo saya lihat-lihat ya lembar muhasabah itu bagus. Jadinya introspeksi dirinya jadi lebih terarah, terukur. Bisa dilihat. Hari ini saya ngelakuin ini itu, berarti besok saya harus lebih baik (mengisi) point-point nya. Jadi ada eval uasinya dalam setiap harinya. Saya juga sering membatin, ngeritik diri sendiri. Kenakalan-kenakalan yang terus menerus dilakukan ya kita nantinya jadi nggak berubah. Apalagi besok mau lulus, kuliah, kerja. Masak besok kalo udah tua nakal terus. Biasanya kalo mau tidur malam. Saya batin. Kok saya ngelakuin kenakalan itu. Jadinya saya nggak mau lagi lah [Ardiyantara, 2017]."

Hal serupa juga disampaikan oleh siswa kelasX IPS 2 yangbernama Zulfan Mumtaz bahwa:

"Saya menyesal atas semua kenakalan saya, mas. Gak mau ngulangin lagi. Saya selalu punya keinginan berubah menjadi lebih baik. Gak cuma pas renungan aja. Selamanya saya pengen berubah jadilebih baik. Muhasabah diri juga. Misal saya nggak komplit ngisi lembar itu, mesti kita kan mikir. Masa hari ini saya cuma ngelakuin kebaikan ini aja. Besoknya saya bisa lihat kebaikan apa aja yang bakal saya lakukan biar bisa komplit semua (point) nya. Harus tambah -tambah lagi gitu. Dulu saya pernah dikasih lembarginian, tapi dinilai. Jadinya saya ada perasaan ingin dapet nilai bagus. Tapi kali ini lembar yang di kasih sama ustadz bilangnya gak dinilai. Biar bisa introspeksi diri. Biar sadar sendiri, gak ketergantungan sama nilai. Jadi yang saya lakukan ya itu mas, ingin berubah menjadi lebih baik [Mumtaz, 2017]."

Berdasarkan pernyataan di atas dapat kita pahami bahwa ini merupakan bentuk realisasi beberapa tingkat muhasabah diri yang berupa mu'atabah, yakni perbuatan mengkritik diri sendiri supaya tidak mengulangi perbuatan dan kesalahan yang pernah ia lakukan sekaligus realisasi bentuk muhasabah diri berupa muraqabah. Selain itu, berdasarkan analisis serta observasi penulis, di dapati bahwa dengan 
Khazanah Pendidikan Islam, Vol. 2 No. 3: 126-138

Muhasabah Diri Sebagai Media Penanggulangan Perilaku Juvenile Delinquency

Iqbal Syafri et.all

adanya kegiatan bimbingan dan konseling dengan pendekatan client centered therapy yaitu berubab muhasabah diri telah memberikan kesan yang positif dan juga efektif dalam melakukan pencegahan terhadap perbuatan-perbuatan juvenile delinquency diantara para peserta didik khususnya bagi siswa kelas X Aliyah Madrasah Muallimin Muhammadiyah. Hasil pencapaian muhasabah peserta didik dapat dilihatpadatabel 3 .

Tabel 3. Hasil Pencapaian Muhasabah Peserta Didik

\begin{tabular}{|c|c|c|c|}
\hline Subjek & $\begin{array}{c}\text { Keadaan } \\
\text { Sebelum } \\
\text { Muhasabah Diri }\end{array}$ & $\begin{array}{c}\text { Keadaan Sesudah } \\
\text { Muhasabah Diri }\end{array}$ & Interpretasi \\
\hline Zulfan Mumtaz & $\begin{array}{l}\text { Siswa sering } \\
\text { melakukan } \\
\text { kenakalan- } \\
\text { kenakalan yang } \\
\text { bersifat melawan } \\
\text { status, kenakalan } \\
\text { yang } \\
\text { menimbulkan } \\
\text { korban fisik, dan } \\
\text { pernah } \\
\text { melakukan } \\
\text { kenakalan yang } \\
\text { menimbulkan } \\
\text { korban materi, } \\
\text { seperti; merokok, } \\
\text { keluar asrama } \\
\text { tanpa izin, } \\
\text { melakukan } \\
\text { kekerasan fisik } \\
\text { dan } \\
\text { pengerusakan } \\
\text { sarana madrasah. }\end{array}$ & $\begin{array}{l}\text { Siswa mau mengakui } \\
\text { dan menyadari } \\
\text { kesalahan-kesalahan } \\
\text { yang pernah dilakukan. } \\
\text { Siswa telah } \\
\text { mempraktikkan bentuk } \\
\text { muhasabah berupa } \\
\text { mu'atabah yakni } \\
\text { perilaku kritik jiwa serta } \\
\text { mujahadah yaitu } \\
\text { optimalisasi ibadah di } \\
\text { hari-hari berikutnya. }\end{array}$ & $\begin{array}{l}\text { Siswa mengalami } \\
\text { keterbukaan } \\
\text { sebagai individu } \\
\text { yang utuh dan } \\
\text { mampu } \\
\text { melakukan upaya } \\
\text { maksimal dalam } \\
\text { meninggalkan } \\
\text { kebiasaan perilaku } \\
\text { kenakalan- } \\
\text { kenakalan } \\
\text { remajanya. } \\
\text { Sehingga kegiatan } \\
\text { muhasabah diri } \\
\text { memiliki hasil } \\
\text { yang positif. }\end{array}$ \\
\hline & $\begin{array}{l}\text { Siswa sering } \\
\text { melakukan tindak } \\
\text { kenakalan remaja } \\
\text { berupa kenakalan } \\
\text { yang bersifat } \\
\text { melawan status } \\
\text { dan kenakalan } \\
\text { sosial yang tidak } \\
\text { melibatkan orang } \\
\text { lain, seperti; } \\
\text { merokok, keluar } \\
\text { asrama tanpa izin, }\end{array}$ & $\begin{array}{l}\text { Siswa mulai mampu } \\
\text { mengorganisasikan } \\
\text { dirinya, mengakui } \\
\text { kesalahannya, dan } \\
\text { memiliki komitmen } \\
\text { untuk berubah menjadi } \\
\text { lebih baik. Siswa mulai } \\
\text { sadar dan membuka } \\
\text { dirinya terhadap hal-hal } \\
\text { yang positif melalui } \\
\text { kegiatan muhasabah }\end{array}$ & $\begin{array}{l}\text { Siswa memiliki } \\
\text { motivasi tinggi } \\
\text { untuk mengatasi } \\
\text { masalah yang } \\
\text { terpusat melalui } \\
\text { dirinya dan } \\
\text { merencanakan } \\
\text { perbuatan positif } \\
\text { yang akan } \\
\text { dilakukan di } \\
\text { kemudian hari. } \\
\text { Kegiatan }\end{array}$ \\
\hline
\end{tabular}




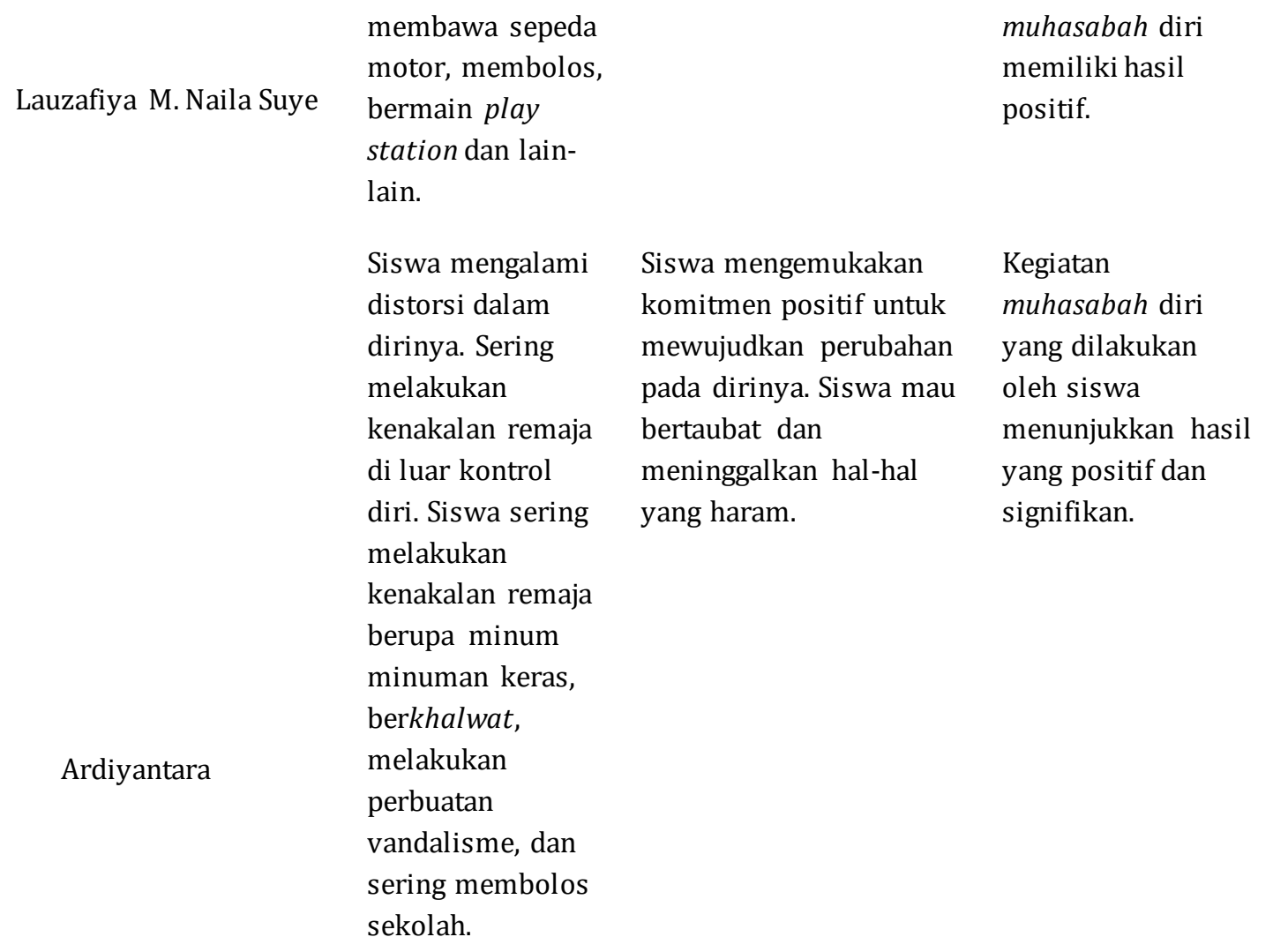

\section{SIMPULAN}

Berdasarkan hasil penelitian serta pembahasan yang penul is paparkan dapat disimpulkan bahwa perbuatan juvenile delinquency yang terjadi di kelas X Aliyah Madrasah Muallimin Muhammadiyah memiliki berbagai bentuk,pola dan di latar belakangi berbagai faktor. Namun, melalui kegiatan muhasabah diri berupa client centered theraphy seperti muraqabah, muhasabah, mujahadah, dan mu'atabah telah menunjukkan hasil yang positif dalam menanggulangi kenakalan remaja (Juvenile Delinquency) di kelas X Madrasah Muallimin Muhammadiyah dimana para peserta didik berkomitmen untuk berhenti mengulangi perbuatan kenakalan remajanya,

\section{DAFTAR PUSTAKA}

Al-'Ulyawi, Shalih. (2007). Muhasabah An Nafs. Riyadh: Maktab Dakwah dan Bimbingan Jaliyat Rabwah.

Anwar, Dedik Fatkul. (2017). Wawancara Wakil Direktur Madrasah di Madrasah Muallimin Muhammadiyah Yogyakarta pada pukul 10.00 WIB - 11.00 WIB, 17 Mei.

Ardiyantara. (2017). Wawancara siswa kelas X IPS 2 di asrama pada pukul 20.15-21.00 WIB, 27 Mei.

Arifin, M. (2006). Pedoman Pelaksanaan Bimbingan dan Penyuluhan Agama. Jakarta: PT Golden Terayon Press.

Asyhari, Muh. (2013). Program Musyrif Untuk Meningkatkan Motivasi Belajar Siswa Kelas XII Madrasah Muallimin Muhammadiyah Yogyakarta. Skripsi UIN Sunan Kalijaga, Yogyakarta. 
Azhar, Muhammad. (2014). Dahsyatnya Energi Syukur, Istighfar. Muhasabah, Solo: As-Salam Publishing.

Bachrun, Saifuddin. (2011). Manajemen Muhasabah Diri. Bandung: PT Mizan Pustaka.

Basewed, Anies Fahmi. (2017). Wawancara Guru BK siswa kelas X Aliyah di asrama pada pukul 09.00-10.00 WIB, 25 Mei.

Daradjat. Zakiah. (2007). Kesehatan Mental. Jakarta: Gunung Agung.

Depdiknas. (2008). Kamus Besar Bahasa Indonesia. Jakarta: Balai Pustaka.

Karzon, Anas Ahmad. (2012). Tazkiyatun Nafs (Gelombang Energi Penyucian Jiwa Menurut Al-Qur'an dan As-Sunnah di atas Manhaj Salafus Shalih). (Jakarta Timur: Akbar Media.

Mahmud. (2011). Pemikiran Pendidikan Islam. Bandung: Pustaka Setia, 2011).

Mubārakfūrī, Muḥammad 'Abd al-Raḥmān ibn 'Abd al-Rahịm. (1963). Tuḥfat al-aḥwadhī bi-sharḥ Jāmi' al-Tirmidhī. Beirut: Mațba'at al-Madanī.

Mumtaz, Zulfan. (2017). Wawancara siswa kelas X IPS 2 di asrama pada pukul 20.00-21.00 WIB, 24 Mei.

Munawwir, Ahmad Warson. (1997). Kamus Al-Munawwir Bahasa Arab-Indonesia Terlengkap. Surabaya: Pustaka Progresif.

Noor, Ahmad Syauqi. (2014). , Strategi Musyrif (Pendamping Asrama) dalam Meningkatkan Perilaku Ibadah Siswa di Asrama Umar Bin Khattab Madrasah Muallimin Muhammadiyah Yogyakarta. Skripsi UIN Sunan Kalijaga, Yogyakarta.

Oktavianto, Sidiq. (2017). Wawancara musyrifkelas X IPS 2 di Madrasah Muallimin Muhammadiyah Yogyakarta pada pukul 18.00-19.00 WIB, 27 Mei.

Rifa'i, Aan Fauzan. (2009). Kenakalan Remaja di Kalangan Santri Putera di Asrama Diponegoro Pondok Pesantren Yayasan Ali Maksum Krapyak Yogyakarta. Skripsi UIN Sunan Kalijaga, Yogyakarta.

Sudarsono. (2004). Kenakalan Remaja: Prevensi, Rehabilitasi, dan Resosialisasi. Jakarta: Rineka Cipta.

Suye, Lauzafia M. Naila. (2017) Wawancara siswa kelas X IPS 2 di asrama pada pukul 20. 